\title{
Rousing the Rabble: Coercion, Coordination, and Regime Change
}

\author{
Terence K. Teo* \\ Assistant Professor, Department of Political Science and Public Affairs, Seton Hall University, South Orange,
} NJ 07079

*Corresponding Author: Terence K. Teo, Assistant Professor, Department of Political Science \&amp; Public Affairs, Seton Hall University South Orange, NJ 07079

\begin{abstract}
Despite compelling logical foundations, distributive conflict theories of democratization have received only mixed empirical support. This paper tests the core mechanism underlying the relationship between income inequality and democratization posited in influential political economy models. I argue that the effects of income inequality on the prospects of democracy are contingent on the social and political resources available to the principal actors. In particular, effective distributive challenges to authoritarian regimes "from below" will depend on the capacity of the masses to overcome coordination and collective action barriers, and on the ability of the elites to marshal capable and reliable instruments of coercion. I test this argument with a time-series cross-sectional design that analyses data on distributive conflict transitions for up to 95 authoritarian regimes between 1980 and 2008. I find that-when the masses can mobilize and the elites are weak-inequality has a predictable and positive effect on the chances for democratization.
\end{abstract}

\section{INTRODUCTION}

Recent political economy models of redistribution have renewed the longstanding interest between inequality and democratization. ${ }^{1}$ A stylized account of the inequality-democratization relationship goes as follows: rising inequality generates demands from the masses for redistribution via democracy, which increases pressure on ruling elites to acquiesce to democratic reforms. However, ruling elites are aware of the risks that suffrage expansion poses to their position at the apex of the income pyramid. At high levels of inequality, demands for redistribution intensify, but elites will deploy their resources to resist regime change. ${ }^{2}$ Specific models differ in important detail, but redistributive theories generally posit that regime change is a function of three factors: the level of economic inequality, the mobility (specificity) of assets, and the costs of repression.

Despite the sound theoretical foundations of these models, efforts to test the effects of income inequality on democratization have so far received inconsistent empirical results. Differences in empirical approaches, samples, and measures notwithstanding, these run the gamut from no effect, ${ }^{3}$ negative effect, ${ }^{4}$ positive effect, ${ }^{5}$ to non-linear dome-shaped effect. ${ }^{6}$ Yet more recent work suggests that the impact of inequality may depend on other factors such as asset mobility, ${ }^{7}$ economic development, ${ }^{8}$ and collective action. ${ }^{9}$ What explains these conflicting findings? By focusing on either protest or revolution, or coups and elite conflict separately, I argue that existing theories only partially explain the tensions that underlie the complex phenomenon of democratization. This emphasis on either "bottom-up" or "top-down" dynamics, in turn, translates to mixed quantitative results.

I claim that whether inequality leads to distributive conflict and democratization depends on the social and political resources available to the principal actors. On the one hand, inequality can intensify the mobilization of demands for democracy when the masses possess occupational or organizational resources that allow them to overcome barriers to coordination and collective action. On the other hand, where such resources are limited, inequality should not be expected to play a role; either transitions would not occur at all, or they would occur through a non-distributive route. At the same time, the elites' decision to acquiesce to redistributive demands will depend ultimately on their capacity to repress mass challenges by force. While the cost of redistribution may increase at higher levels of inequality, the cost of repression will depend independently on the loyalty and capacity of the military and security forces. The odds that the elite will give in to mobilized demands for democracy will diminish when it controls a loyal and capable repressive apparatus; where coercive resources are limited, such transitions can occur even when inequality is quite high. 
This paper makes two contributions to the political economy of democratic transitions. First, by focusing on distributive conflict transitions, I clarify how and why these differ from democratization processes that pass through different routes, such as elite-led transitions. My findings suggest, in other words, that transitions are not all alike; different types of transition may require different theories of democratization. Second, to my knowledge, this is the first study to assess the joint effects of coordination and coercive capacity on the impact of income inequality on democratization. In particular, I find that the effects of inequality on democratization depend on both the ability of the masses to overcome coordination and collective action problems and the ability of the elites to repress.

\section{INEQUALITY, DiSTRIBUTIVE CONFLICT, AND DEMOCRATIZATION}

Economic factors have always loomed large in the study of democratization. Modernization theory regards economic development as central to the formation of democracy ${ }^{10}$ whereas the "survival" story argues that the level of development is key to sustaining democracy once established. ${ }^{11}$ Today, another economic variable - inequality - is once again at the core of the dominant theories of democratization. While variants of these theories exist, they share the notion that the masses react to their economic situation and either accept the authoritarian status quo or seek to change it (by demanding democracy).

The Meltzer-Richard mode $\mathrm{l}^{12}$ provides the basis for much of the formal transition theory. ${ }^{13}$ Meltzer and Richard's core propositions are that government tax rate decisions rest on the preferences of the median voter. As income becomes increasingly right-skewed, the median voter will demand higher levels of taxation in anticipation of redistributive benefits. The model assumes thatsuch decisions are made within the framework of a democratic regime, in which governments are responsive to voter demands, and parties competing in the electoral arena have to register the median voter's preferences on tax redistribution. ${ }^{14}$ Although the most influential extensions of the Meltzer-Richard model share the assumption that democratic governments will respond to voter preferences for redistribution, they begin instead with a society ruled not by a democracy, but by an authoritarian regime where elites seek to protect their economic assets through restrictions on suffrage. ${ }^{15}$

To do this, these theories make three assumptions: First, all governments, authoritarian or otherwise, respond to (some) citizen demands. Second, the masses expect redistribution under democracy. Third, the masses can effectively mobilize in response to economic conditions. The first assumption is uncontroversial: even the most vicious or charismatic rulers must ensure that the citizenry is pliant and passive, if not by force, then by honey. The second assumption follows from the results of Meltzer and Richard, though there is little evidence that democracies are more redistributive, or have lower inequality. ${ }^{16}$ The third assumption is more problematic: it ignores the considerable coordination and collective action problems that the masses have to overcome to mobilize and organize to express their demands. These assumptions, combined with Meltzer and Richard's propositions, give rise to a body of work that Haggard and Kaufman call distributive conflict theories of regime change, ${ }^{17}$ and what Ansell and Samuels coin the redistributivist thesis. ${ }^{18}$ First articulated by Boix, and Acemoglu and Robinson, these arguments relate the level of income inequality to mass demands for redistribution, elite considerations over the costs and benefits of democratization, and subsequent prospects for democracy.

Initial challenges to an authoritarian regime depend to a considerable extent on demands that are mobilized outside the electoral arena-through what Acemoglu and Robinson call the de facto power of strikes, demonstrations, and other threats to the security of the elites. ${ }^{19}$ The response of elites will depend, in turn, on how they perceive the costs of toleration and repression. This leads Boix and Acemoglu and Robinson to somewhat different conclusions about when democracy is likely to emerge. For Boix, a transition is most likely to occur at low levels of inequality, where the costs of redistribution and regime change are lowest for the ruling elite. ${ }^{20}$ For Acemoglu and Robinson, a transition is most likelyto arise at middle levels of inequality, where incentives for the masses to mobilize threats against the status quo are stronger, but the costs of concession are still reasonably tolerable for the elites. ${ }^{21}$ Both Boix, and Acemoglu and Robinson, however, argue that the toleration/repression calculus of the elite will become increasingly unfavorable where assets and income are highly concentrated.

These two influential arguments spawned a vibrant debate in the comparative democratization scholarship. Whereas the focus of the latter half of the twentieth century-from Lipset's 
modernization hypothesis to Przeworski's survival hypothesis-was economic development, economic inequality is the locus of scholarship in the twenty-first century. Unfortunately, evidence against distributive conflict theories is mounting. Houle finds no support for either a linear or inverted-U shaped relationship between inequality - as measured by capital's share of manufacturing income - and the probability of democracy. ${ }^{22}$ His analysis, however, suggests that inequality reduces the prospects of democratic consolidation. Distinguishing between land and income inequality, Ansell and Samuels find that higher income inequality increases the probability of democratization, and argue that this reflects the emergence of middle-class and commercial groups with an interest in pressing for expanded suffrage. They further show how land equality-measured using a modified Vanhanen's family farm measure adjusted by the relative size of the rural population-makes democratization more likely. ${ }^{23}$

Building on Boix, Freeman and Quinn find that asset mobility conditions the democratizing effect of inequality. ${ }^{24}$ High inequality makes democratization more likely in financially open economies compared to closed ones, since greater capital mobility presents an exit option to elites, thereby reducing the risks from redistribution. Combining insights from modernization and distributive conflict theories, Houle finds that the level of economic development conditions the effects of inequality: inequality has no effect on democratization in low-income dictatorships, increases the prospects for democratization in middle-income dictatorships, and is harmful in high-income dictatorships. ${ }^{25}$

In a departure from statistical models, Haggard and Kaufman examine all democratic transitions from 1980 to 2008 using causal process observations, and find that distributive conflict - a core causal mechanism of the inequality hypothesis - exists in only slightly more than half of all transition cases (42 of 78 transitions using Cheibub, Ghandi, and Vreeland's coding, and 37 of 73 transitions using Polity IV) ${ }^{26}$ What is more, transitions occur at high levels of inequality in a startling number of cases, a result at odds with both Boix's, and Acemoglu and Robinson's variants of the distributive conflict hypothesis, ${ }^{27}$ but consistent with Ansell and Samuels' analysis. ${ }^{28}$

On the theoretical front, these analytic stories rests on two largely implicit assumptions. The first is that the masses - once motivated to protest against inequality and demand redistribution — will be able to overcome barriers to coordination and collective action and mobilize in favor of democracy. The second is that the elites have the capacity to repress such threats if they perceive that the cost of redistribution is too high. Both assumptions, however, warrant much closer scrutiny. As Olson argued more than fifty years ago, the free-rider problem poses a puzzle in the rational behavior of groups. ${ }^{29}$ This issue is not crucial for the Meltzer-Richard model itself, which is based on decisions made by individual voters rather than organized groups, but formal models of transition, as discussed earlier, hinge on the ability of low-income groups to mobilize outside the electoral arena. To be sure, these theories do not entirely ignore the collective action issue. Boix argues that - as inequality declinessubordinate groups will have greater access to informational and economic resources that enhance the capacity for mobilization, ${ }^{30}$ and both Boix, and Acemoglu and Robinson suggest that this capacity will be enhanced by economic development and the emergence of class divisions in capitalist economies. ${ }^{31}$ However, these concerns do not play a central role in their analysis and are elided almost entirely in empirical tests of the theory.

Similarly, despite a substantial literature on how repression and a strong coercive apparatus can prolong authoritarian survival, ${ }^{32}$ variations in the resources available to elites in distributive conflict theories receive only lip service. While Boix, and Acemoglu and Robinson assume that the relative cost of repression will grow with increasing inequality, there is little discussion of the factors that influence the extent to which elites can command a loyal and capable coercive apparatus, or how that might affect the assessment of repression costs. ${ }^{33}$ The empirical literature is also largely silent on this issue. Houle argues that the link between inequality and transitions is indeterminate, because the cost of toleration and repression will both rise with increasing inequality. ${ }^{34} \mathrm{He}$ demonstrates this empirically as well, but does not otherwise assess variations in the cost of repression. Freeman and Quinnfind that inequality affects transitions when the economic openness of the authoritarian regime is taken into account. ${ }^{35}$ However, they do not systematically discuss the political resources available to the elites, or how these resources are deployed in transition situations. A notable exception is Albertus and Menaldo, who find that higher coercive capacity, as proxied by military size, reduces the likelihood of democratization. ${ }^{36}$ What is more, while recent work examines how either collective 
action or coercive capacity influences the prospects for democratization, no study, to my knowledge, explores the joint effects of both factors, and how both factors condition the effects of inequality on democratization. Existing scholarship, if they do at all, examines the effects of inequality, collective action, or coercive capacity separately.

Finally, neither these works nor others distinguish between different transition paths; almost all quantitative work to date either deploy a single binary variable to code whether or not a transition has occurred or use point changes in a regime's Polity score ${ }^{37}$ However, these measures merely indicate whether a transition took place, and do not capture whether distributive conflict played a role. This is problematic since distributive conflict theories place primacy on redistributive struggles over income, and view democratization as the successful outcome of these struggles given some inequality threshold. Yet as Haggard, Kaufman and Teo show, distributive conflict is not only absent in approximately half of all transitions to democracy, but present across all levels of inequality. ${ }^{38}$ Consequently, empirical studies that fail to differentiate between transitions do not actually test the core underlying mechanism in the theory that inequality fosters democratization as a consequence of distributive conflict.

As such, I draw on the distinction between distributive conflict and elite-led transitions elaborated in Haggard, Kaufman, and Teo in this paper. ${ }^{39}$ Distributive conflict transitions are defined as transitions in which: (a) the threat of mass mobilization is at least one of the challenges faced by ruling elites, (b) economic grievances constitutes at least one of the motives for mobilization, and (c) the elites acquiesce to democracy partly in response to these threats. Elite-led transitions are not driven by this sequence of threats and response; they work through other channels such as conflicts within the elite itself and/or international pressures. A distributive conflict transition can thus be characterized as a (largely) "bottom-up" transition, and its elite-led counterpart, a (largely) "top-down" transition.

\section{Coordination, Collective ACtion, And Coercion}

I contend that distributive conflict theories might hold up better if their scope were more clearly delineated, particularly by examining how the capacity of the masses to coordinate and the ability of elites to repress moderate the effects of income inequality. Consider first the position of potential challengers in an authoritarian regime. As inequality rises, such challengers may well prefer redistribution-and following Meltzer and Richard-will demand democracy. ${ }^{40}$ To challenge the incumbent regime, however, these lower-income groups must not only act on these preferences, but more critically, overcome the barriers to collective action and coordination they face in ways that raise the threat to elites of instability or revolution. There are many ways these barriers can be overcomeincluding the mobilization of ethnic or geographic ties - but one key factor I emphasize is whether low-income groups are situated in manufacturing occupational structures or related social networks that facilitate coordination, concentration, and communication-whether, in other words, there is room to amass a sizable "proletariat" to launch a rebellion.

Put simply, discontent does not a rabble make. If the masses lack the channels and institutions to organize and coordinate protest, distributive conflict is likely to be absent, irrespective of the level of inequality. Indeed, rising inequality may create greater pressures for the masses to demand democracy, ${ }^{41}$ but any protest hinges on the capacity of the masses for coordination and collective action. At low levels of inequality, relatively moderate threats from well-organized protests might be sufficient to bring about a transition, since the cost of redistribution would be relatively low for the elite. At the same time, however, the elites could co-opt any organized opposition by offering side payments instead of granting democratic concessions. ${ }^{42}$ At middle levels of inequality, the threat from the masses increases, as does the costs of democratization to the elite. However, these costs remain tolerable, and in the face of coordinated mass opposition, the elite is likely to capitulate. ${ }^{43}$ As inequality rises ever higher, collective pressures intensify; this is when the elite is most likely to repress, and consequently, where their coercive capacity is paramount.

Hypothesis 1. As inequality rises, the greater the organizational capacity of the masses, the more likely a distributive conflict transition will occur.

Even assuming that barriers to coordination and collective action can be overcome, elites will be inclined to repress - rather than acquiesce to - these demands, especially at high levels of inequality. To be sure, they may attempt to use the resources of the state to co-opt some of the opposition and to 
isolate others; the institutional resources of one-party regimes may place them in a better position than military regimes to do so. ${ }^{44}$ Regardless of authoritarian regime type, however, cooptation may become less viable as demands for redistribution intensify. Ultimately, the response of the elites will depend on their control over a reliable and effective coercive apparatus. ${ }^{45}$ The greater the elites' coercive capacity, the more likely it is to deter mobilization, and trump mobilization if it arises. Where coercive capacity is low, on the other hand, there is a greater probability that - even at high levels of inequality - eliteswill acquiesce to effectively mobilized demands.

Hypothesis 2. As inequality rises, the greater the coercive capacity of elites, the less likely a distributive conflict transition will occur.

Finally, I contend that the probability of distributive conflict in the face of rising inequality depends on the two key factors discussed above: the ability of the masses to overcome coordination and collective action problems and the ability of the elites to command a strong and reliable coercive apparatus. I further model the conditional effects of inequality on these relationships as linear, rather than the inverted $\mathrm{U}$ posited by Acemoglu and Robinson. ${ }^{46}$ As inequality increases, there is little reason to think that preferences for redistribution would not increase as well, or that - given the capacity to overcome coordination and collective action barriers - the masses would not mobilize at high levels of inequality. Nor is there any reason to believe that - where the coercive apparatus is unreliable or ineffective- elites would not be inclined to acquiesce to these demands, even where the cost of redistribution is high.

Hypothesis 3. As inequality rises, distributive conflict transitions are more likely to occur when (a) organizational capacity is high, and (b) coercive capacity is low.

\section{RESEARCH DESIGN}

To test my hypotheses, I use a time-series cross-sectional (TSCS) design with country-year as the unit of analysis. The dataset includes approximately 115 developing countries from 1980 to 2008, with 4,147 possible country-year observations. I lag all explanatory and control variables by one year, and following Carter and Signorino, include a cubic polynomial to model the temporal dependence of the binary outcome. ${ }^{47}$ To account for cross-country variation (unit heterogeneity), I run non-nested multilevel logit models where level-one units are annual observations of each variable, and level-two units are countries. ${ }^{48}$

\subsection{Outcome}

Distributive conflict transition. The coding of transitions comes from Haggard, Kaufman and Teo's qualitative data set, ${ }^{49}$ which analyzes all transitions between 1980 and 2008 identified in Polity IV, and Cheibub, Ghandi, and Vreeland (hereafter CGV). ${ }^{50} \mathrm{I}$ construct a binary variable that is coded one if a distributive conflict transition occurred in a given year, and zero otherwise. There are $42 \mathrm{CGV}$ distributive conflict transitions, and 37 Polity distributive conflict transitions.

\subsection{Explanatory Variables}

Inequality. Measures of inequality are famously unreliable, especially for developing countries where sampling techniques vary, and coverage is often limited. One reasonable measure among the range of problematic options is the share of capital in the manufacturing sector - capital share-developed by Rodrik (1999), ${ }^{51}$ updated by Rodriguez and Ortega, ${ }^{52}$ and subsequently refined and extended by Christian Houle. ${ }^{53}$ To be sure, the manufacturing sector is quite limited among many of the developing countries included in the sample. However, capital share has the advantage of capturing class divisions (labor versus capital) that have often provided the locus of redistributive struggles. As Dunning (143) states, "capital shares represent the best available cross-national indicator of private inequality." ${ }^{, 54}$ As a check on this measure, I substitute the Gini coefficient for capital share from Solt's Standardized World Income Inequality Database due to its coverage across space and time. ${ }^{55}$

Coordination Capacity. Again, the availability of reliable measures poses an important constraint. My main proxy is the value added in manufacturing as a percentage of GDP. ${ }^{56}$ As Haggard and Kaufman argue, a large manufacturing sector gathers like-minded individuals together, creates the conditions that facilitate communication and coordination of shared interests, and decreases the costs of collective action. ${ }^{57}$ I acknowledge that this is a measure of the potential for coordination and collective action, rather than a direct indicator of organizational capacity. However, countries that 
rank high on this variable do include ones with a history of labor militancy such as Argentina, Brazil, Thailand, and South Korea. As a check on this measure, I use union membership per capita from the High Profile Strikes Dataset. ${ }^{58}$

Coercive Capacity. Authoritarian regimes frequently rely on a variety of instruments to threaten or repress the underlying population, from civil rights restrictions to police intimidation. Ultimately, however, they must count on the support of the military establishment, even if it is not typically regarded as the first line of defense. As Dahl (250) notes, "nondemocratic regimes employ the superior coercive resources of the military and police to maintain their rule. ${ }^{, 59}$ Similarly, Albertus and Menaldo (153) write that, "A dictator can use the military to suffocate pressure for political change emanating from the population or organized parties and movements."

My proxies for coercive capacity focus on two aspects of the military establishment: military size per 100,000 inhabitants (from the Correlates of War Project's National Material Capabilities v4.0 dataset), and a history of coups prior to a transition (from the Center for Systemic Peace's (2011) Coup d'état Events, 1946-2010 dataset). Although many factors can affect military size, such as the presence of foreign threats and interstate disputes, large militaries are more able than small ones to effectively project power throughout a national territory and across population centers (see Levitsky and Way for a similar argument, and Albertus and Menaldo). ${ }^{61}$ In my sample, countries with relatively large militaries include a number which have experienced extended periods of military dictatorship, includingSouth Korea, Uruguay, El Salvador, and Guatemala.

Whereas size reflects the military's capabilities, a history of coups serves as an indicator of the military's reliability. Where elites have experienced coups in the past - or when they themselves have used the military as a channel for seizing power-it is less likely that they can count on the armed forces to protect them during periods of social upheaval. I thus expect that the probability of a distributive conflict transition varies inversely with the size of the military, and directly with a history of prior coups.

\subsection{Interaction Effects}

To assess how coordination and coercive capacity condition the impact of inequality on the likelihood of a transition, I construct multiplicative interaction terms: inequality $\times$ coordination capacity and inequality $\times$ coercive capacity. Testing Hypothesis 3 requires a three-way interaction term: inequality $\times$ coordination capacity $\times$ coercive capacity. However, coefficients on three-way interaction terms are unreliable and difficult to interpret. As such, I subset the data into low and high levels of coordination and coercive capacity using their respective medians as cutoffs, and run two-way interactions instead.

\subsection{Control Variables}

Finally, I account for other factors that could affect the probability of a distributive conflict transition. The usual suspects include: log Gross Domestic Product (GDP) per capita and GDP growth, both from the World Development Indicators ${ }^{62}$ ethnic fractionalization; ${ }^{63}$ resource rents as a percentage of GDP, ${ }^{64}$ the proportion of neighboring democracies, and the number of previous democratic breakdowns. ${ }^{65}$ Following Freeman and Quinn, I include as well Chinn-Ito's measure of capital openness to control for the likelihood that both the extent of mobilization and coercion may be affected by the availability of exit options for capital. ${ }^{66}$

Table1 presents summary statistics of the variables in the analysis.

Table1. Summary Statistics

\begin{tabular}{|l|l|l|l|}
\hline Variable & $\mathrm{N}$ & Mean & SD \\
\hline Outcome & & & \\
\hline capital share (Houle) & 3,806 & 0.67 & 0.09 \\
\hline Gini (Solt) & 2,362 & 40.56 & 8.99 \\
\hline Predictors & & & \\
\hline manufacturing (\% of GDP) & 3,166 & 14.61 & 8.01 \\
\hline union membership & 3,356 & 2.94 & 3.99 \\
\hline military size (log) & 2,464 & -0.77 & 1.03 \\
\hline prior coup & 3,871 & 0.10 & 0.30 \\
\hline Controls & & & \\
\hline per capita GDP $(\log )$ & 3,553 & 8.04 & 1.12 \\
\hline
\end{tabular}


Rousing the Rabble: Coercion, Coordination, and Regime Change

\begin{tabular}{|l|l|l|l|}
\hline growth $(\%)$ & 3,620 & 3.63 & 7.08 \\
\hline resource income $(\log )$ & 3,412 & -2.52 & 1.98 \\
\hline capital openness & 6,540 & 0.43 & 0.35 \\
\hline ethnolinguistic fractionalization & 3,206 & 0.40 & 0.31 \\
\hline neighbouring democracies & 3,282 & 0.26 & 0.29 \\
\hline previous democratic breakdowns & 3,662 & 0.43 & 0.78 \\
\hline
\end{tabular}

\section{RESULTS}

Table 2 presents mixed effects logit estimates for the effects of inequality, coordination, and coercion on the likelihood of a CGV distributive conflict transition. Across all models, income inequality has no effect on the likelihood of a distributive conflict transition, a finding consistent with Houle, and Haggard and Kaufman. ${ }^{67}$ The size of the manufacturing sector positively predicts the probability of a distributive conflict transition, which suggests that the greater the potential for coordination and organization, the more likely a transition will occur via mass protest. Union membership has no statistically significant impact on democratization. The coercion variables, however, show more limited results. Whereas the size of the military is not statistically significant, a history of coups increases the likelihood of a transition. Among the control variables, the impact of economic growth is consistently negative across all models, which comports with existing theory that economic growth aids authoritarian regime survival whereas weak economic performance increases the vulnerability of authoritarian regimes.

Table 3 presents the two-way interactions between inequality and the moderators of interest. The results provide support for hypothesis 1 (but not 2). The coefficient estimate of capital share $\times$ manufacturing is statistically significant, which suggests that the effect of inequality on the democratization via distributive conflict depends on the organizational capacity of the masses. Figure 1 shows that the marginal effect of capital share on the likelihood of a distributive conflict transition is positive and statistically significant as the size of the manufacturing sector increases past approximately $17 \%$ (left plot), where the shaded region indicates $95 \%$ confidence intervals. However, there is no significant interaction of capital share $\times$ union membership (right plot).

Table2. Multilevel Logit Estimates on the Likelihood of CGV Distributive Conflict Transition

\begin{tabular}{|c|c|c|c|c|c|}
\hline & 1 & 2 & 3 & 4 & 5 \\
\hline \multirow[t]{2}{*}{ capital share } & 3.46 & 2.43 & 2.64 & 3.16 & 2.91 \\
\hline & 2.14 & 2.26 & 2.19 & 2.10 & 2.11 \\
\hline \multirow[t]{2}{*}{ manufacturing } & & $0.07^{* * *}$ & & & \\
\hline & & 0.03 & & & \\
\hline \multirow[t]{2}{*}{ union membership } & & & -0.03 & & \\
\hline & & & 0.07 & & \\
\hline \multirow[t]{2}{*}{ military size } & & & & -0.15 & \\
\hline & & & & 0.25 & \\
\hline \multirow[t]{2}{*}{ prior coups } & & & & & 0.93 \\
\hline & & & & & 0.56 \\
\hline \multirow[t]{2}{*}{ per capita GDP } & -0.08 & -0.55 & -0.05 & -0.01 & -0.04 \\
\hline & 0.31 & 0.34 & 0.32 & 0.33 & 0.31 \\
\hline \multirow[t]{2}{*}{ growth } & $-0.05^{* *}$ & $-0.06^{* *}$ & $-0.05^{* *}$ & $-0.05^{* *}$ & $-0.04^{*}$ \\
\hline & 0.02 & 0.03 & 0.02 & 0.02 & 0.02 \\
\hline \multirow[t]{2}{*}{ resource income (log) } & -0.20 & -0.18 & -0.21 & -0.21 & -0.20 \\
\hline & 0.14 & 0.18 & 0.17 & 0.16 & 0.16 \\
\hline \multirow[t]{2}{*}{ capital openness } & -0.39 & 0.50 & -0.66 & -0.40 & -0.39 \\
\hline & 0.79 & 0.86 & 0.85 & 0.79 & 0.79 \\
\hline \multirow[t]{2}{*}{ ethnolinguistic fractionalization } & -0.18 & 0.42 & -0.39 & -0.32 & -0.22 \\
\hline & 0.90 & 0.83 & 0.94 & 0.90 & 0.89 \\
\hline \multirow[t]{2}{*}{ neighbouring democracies } & -0.89 & -0.46 & -1.00 & -0.96 & -0.77 \\
\hline & 1.08 & 1.10 & 1.12 & 1.09 & 1.07 \\
\hline \multirow[t]{2}{*}{ previous democratic breakdowns } & $0.45^{\text {*** }}$ & $0.49^{* * *}$ & $0.48^{\text {*** }}$ & $0.44^{*}$ & $0.40^{* * 2}$ \\
\hline & 0.20 & 0.23 & 0.22 & 0.20 & 0.20 \\
\hline var(country intercept) & 0.00 & 0.00 & 0.00 & 0.00 & 0.00 \\
\hline $\mathrm{N}$ & 2,574 & 2,299 & 2,381 & 2,548 & 2,574 \\
\hline Countries & 117 & 115 & 114 & 117 & 117 \\
\hline AIC & 296.9 & 255.7 & 208.6 & 298.3 & 296.5 \\
\hline $\mathrm{BIC}$ & 361.3 & 324.6 & 349.9 & 368.4 & 366.8 \\
\hline
\end{tabular}


Robust standard errors are shown in italics. All explanatory and control variables are lagged by one year. Intercepts estimated but not reported. ${ }^{* * *},{ }^{* *}$, and ${ }^{* *}$ denote statistical significance at $p<.01, p<.05$ and $p<.10$ respectively.

Table3. Two-Way Interactions on the Likelihood of CGV Distributive Conflict Transition

\begin{tabular}{|c|c|c|c|c|}
\hline & 1 & 2 & 3 & 4 \\
\hline \multirow[t]{2}{*}{ capital share } & -7.48 & 1.27 & 8.36 & 4.26 \\
\hline & 4.59 & 2.54 & 4.00 & 2.41 \\
\hline \multirow[t]{2}{*}{ manufacturing } & $-0.47^{*}$ & & & \\
\hline & 0.24 & & & \\
\hline \multirow[t]{2}{*}{ union membership } & & -0.49 & & \\
\hline & & 0.52 & & \\
\hline \multirow[t]{2}{*}{ military size } & & & $-2.55^{*}$ & \\
\hline & & & 1.53 & \\
\hline \multirow[t]{2}{*}{ prior coups } & & & & 5.44 \\
\hline & & & & 3.42 \\
\hline \multirow[t]{2}{*}{ capital share $\times$ manufacturing } & $0.73^{\text {*** }}$ & & & \\
\hline & 0.32 & & & \\
\hline \multirow[t]{2}{*}{ capital share $\times$ union membership } & & 0.64 & & \\
\hline & & 0.69 & & \\
\hline \multirow[t]{2}{*}{ capital share $\times$ military size } & & & 3.37 & \\
\hline & & & 2.13 & \\
\hline \multirow[t]{2}{*}{ capital share $\times$ coup } & & & & -6.11 \\
\hline & & & & 4.69 \\
\hline \multirow[t]{2}{*}{ per capita GDP } & $-0.67^{*}$ & -0.04 & -0.07 & -0.04 \\
\hline & 0.36 & 0.32 & 0.33 & 0.31 \\
\hline \multirow[t]{2}{*}{ growth } & $-0.05^{*}$ & $-0.05^{* *}$ & $-0.05^{* * *}$ & $-0.05^{* *}$ \\
\hline & 0.03 & 0.02 & 0.02 & 0.02 \\
\hline \multirow[t]{2}{*}{ resource income $(\log )$} & -0.18 & -0.22 & -0.18 & -0.19 \\
\hline & 0.19 & 0.17 & 0.17 & 0.16 \\
\hline \multirow[t]{2}{*}{ capital openness } & -0.55 & -0.59 & -0.33 & -0.37 \\
\hline & 0.85 & 0.85 & 0.81 & 0.79 \\
\hline \multirow[t]{2}{*}{ ethnolinguistic fractionalization } & -0.31 & -0.41 & -0.38 & -0.22 \\
\hline & 1.04 & 0.94 & 0.90 & 0.89 \\
\hline \multirow[t]{2}{*}{ neighbouring democracies } & -0.49 & -1.08 & -1.18 & -0.83 \\
\hline & 1.13 & 1.13 & 1.15 & 1.08 \\
\hline \multirow[t]{2}{*}{ previous democratic breakdowns } & 0.39 & $0.45^{* * *}$ & $0.44^{* * *}$ & $0.40^{\text {*** }}$ \\
\hline & 0.24 & 0.22 & 0.20 & 0.20 \\
\hline $\operatorname{var}($ country intercept $)$ & 0.00 & 0.00 & 0.00 & 0.00 \\
\hline $\mathrm{N}$ & 2,299 & 2,381 & 2,548 & 2,574 \\
\hline Countries & 117 & 114 & 117 & 117 \\
\hline AIC & 296.9 & 281.7 & 297.8 & 296.9 \\
\hline $\mathrm{BIC}$ & 361.3 & 356.7 & 373.8 & 373.0 \\
\hline
\end{tabular}

Robust standard errors are shown in italics. All explanatory and control variables are lagged by one year. Intercepts estimated but not reported. ${ }^{* * *},{ }^{* *}$, and ${ }^{* *}$ denote statistical significance at $p<.01, p<.05$ and $p<.10$ respectively.
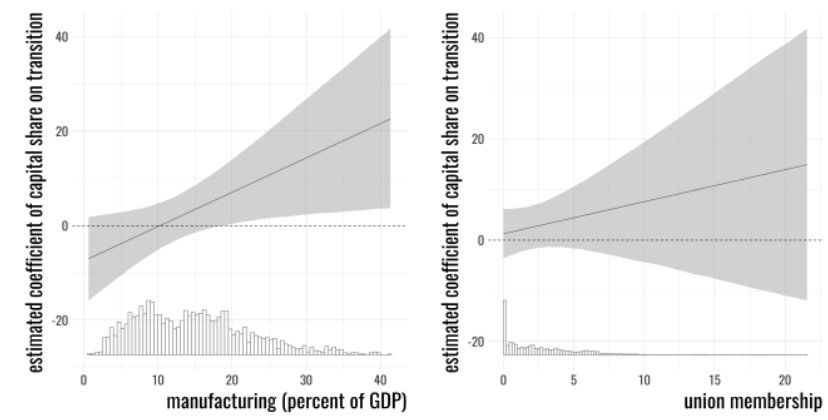

Figure 1. Marginal Effect of Inequality and Coordination on Distributive Conflict Transition 
The lines and shaded regions indicate the estimated coefficient and its associated 95\% confidence intervals respectively. The histogram displays the distribution of the manufacturing (left plot) and union membership (right plot) variables. The coefficient estimate is statistically significant at $p<.05$ where the confidence intervals do not include zero.

With respect to the coercion moderators, there are no statistically significant interactions between inequality and military size or coup history (Table 3, columns 3 and 4). I nonetheless construct marginal effects plots since it is not possible to ascertain whether a conditional effect is meaningful simply by the size and significance of the coefficient estimate. ${ }^{68}$ Figure 2 shows that the marginal effect of inequality on the likelihood of a distributive conflict transition is positive and statistically significant between -1 and 0.5 of logged military size (left plot). This suggests that inequality increases the likelihood of a distributive conflict transition at relatively high levels of military size, which contradicts hypothesis 2 . On the other hand, the marginal effect of inequality and coup history is not statistically significant (right plot).
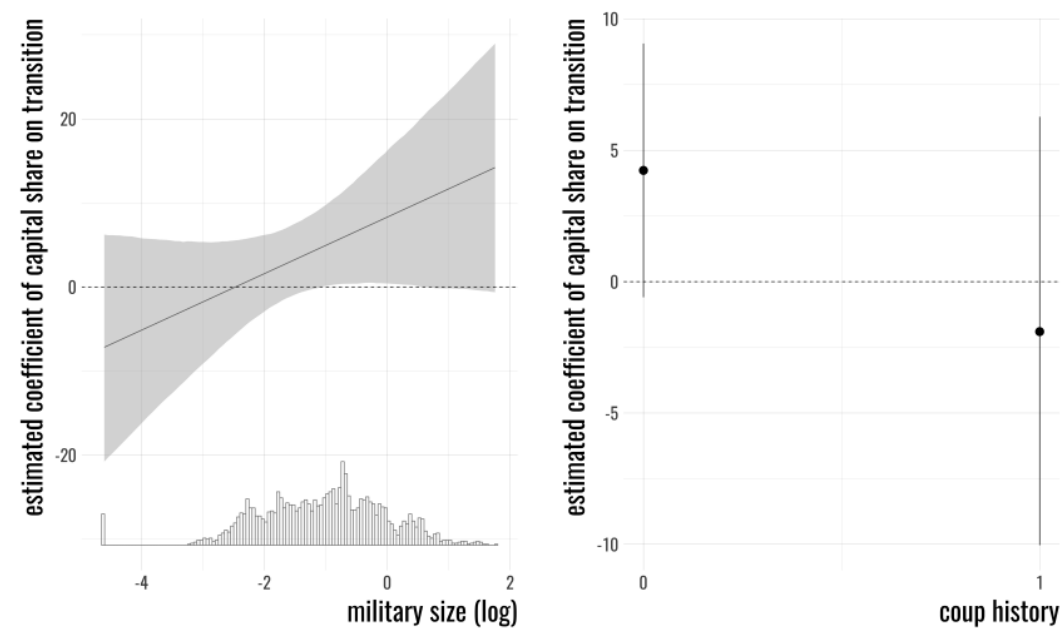

Figure 2. Marginal Effect of Inequality and Coercion on Distributive Conflict Transition

The line and shaded region (left plot)/dot-and-whisker (right plot) indicate the estimated coefficient and its associated 95\% confidence intervals respectively. The histogram displays the distribution of the military size (log) variable. The coefficient estimate is statistically significant at $p<.05$ where the confidence intervals do not include zero.

My core question, however, is whether differences in coercive capacity matter when elites are confronted both with high inequality and mobilized demands for redistribution. I contend that the likelihood of a distributive conflict transition increases as the masses are more capable of presenting an organized threat and the elites are less capable of dealing with such demands. As discussed earlier, I eschew three-way interactions due to their complexity; instead, I subset the dataset into: (1) low and high military size using the median as a cutoff, and (2) whether a coup occurred at any point in a country's history. Table 4 presents the results of this analysis.

Table4. Multilevel Logit Estimates of Collective Action and Coercive Capacity on Distributive Conflict Transition

\begin{tabular}{|l|l|l|l|l|}
\hline & \multicolumn{3}{l|}{ Military Size } & \multicolumn{2}{l|}{ Coup History } \\
\hline & Low & High & Yes & No \\
\hline capital share & -7.83 & 2.81 & $-13.39^{* *}$ & -1.68 \\
\hline & 4.65 & 10.85 & 6.81 & 9.83 \\
\hline manufacturing & $-0.56^{* * *}$ & -0.09 & $-1.04^{*}$ & -0.22 \\
\hline & 0.28 & 0.43 & 0.57 & 0.39 \\
\hline capital share $\times$ manufacturing & $0.80^{* *}$ & 0.24 & $1.39^{* *}$ & 0.43 \\
\hline & 0.36 & 0.56 & 0.71 & 0.53 \\
\hline per capita GDP & -0.36 & -0.56 & -0.96 & -0.51 \\
\hline & 0.42 & 0.50 & 0.85 & 0.39 \\
\hline growth & $-0.06^{* * *}$ & -0.02 & -0.03 & -0.07 \\
\hline & 0.03 & 0.04 & 0.03 & 0.04 \\
\hline resource income (log) & -0.14 & 0.09 & -0.10 & -0.23 \\
\hline
\end{tabular}


Rousing the Rabble: Coercion, Coordination, and Regime Change

\begin{tabular}{|l|l|l|l|l|}
\hline & 0.22 & 0.28 & 0.45 & 0.23 \\
\hline capital openness & 0.04 & -0.41 & 0.29 & 0.26 \\
\hline & 0.87 & 1.38 & 1.43 & 0.95 \\
\hline ethnolinguistic fractionalization & 0.42 & -0.66 & -1.40 & 0.69 \\
\hline & 1.21 & 1.98 & 1.87 & 1.50 \\
\hline neighbouring democracies & -0.34 & -1.53 & -2.26 & -0.82 \\
\hline & 1.18 & 2.46 & 4.02 & 1.25 \\
\hline previous democratic breakdowns & 0.15 & 0.49 & 0.28 & 0.58 \\
\hline & 0.30 & 0.37 & 0.48 & 0.33 \\
\hline var(country intercept) & 0.00 & 0.00 & 0.00 & 0.00 \\
\hline N & 1,665 & 1,155 & 789 & 1,510 \\
\hline Countries & 97 & 79 & 48 & 99 \\
\hline AIC & 214.3 & 119.8 & 110.8 & 157.6 \\
\hline BIC & 279.3 & 180.4 & 166.9 & 221.5 \\
\hline
\end{tabular}

Robust standard errors are shown in italics. All explanatory and control variables are lagged by one year. Intercepts estimated but not reported. ${ }^{* * *},{ }^{* *}$, and ${ }^{* *}$ denote statistical significance at $p<.01, p<.05$ and $p<.10$ respectively.

The coefficient estimates on capital share $\times$ manufacturing are positive and statistically significant in the low military size and coup history samples. Figure 3 shows how the marginal effect of inequality varies with manufacturing size in low and high military size sample. Consistent with hypothesis 3 , the marginal effect of inequality on the likelihood of a distributive conflict transition is positive and statistically significant as manufacturing size increases past $20 \%$ in the low military size sample (left plot). In the high military sample (right plot), however, there is no effect. This suggests that where coercive capacity is low, and as coordination capacity increases past a specific threshold, inequality increases the probability of a distributive conflict transition.
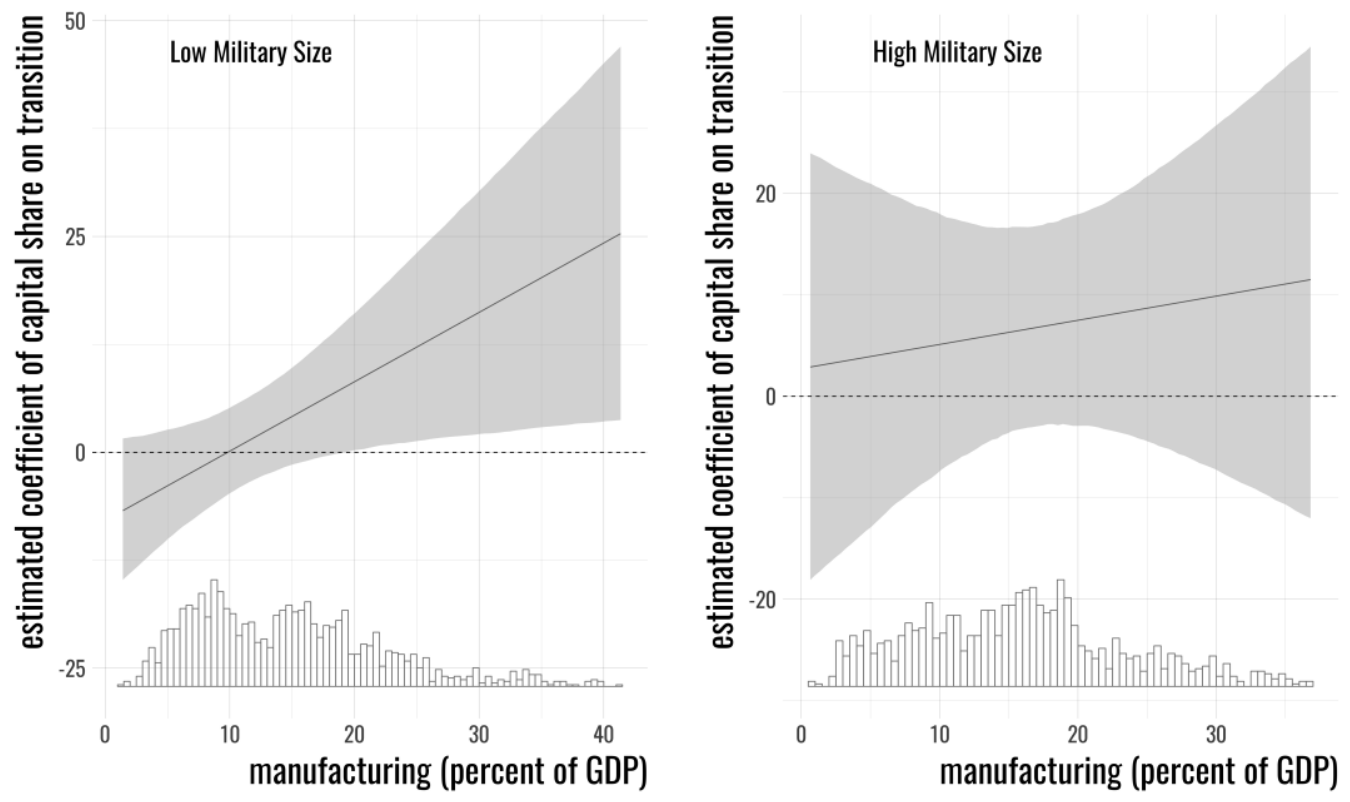

Figure 3. Marginal Effect of Inequality and Manufacturing Sector Size on Distributive Conflict Transition (Military Size)

The lines and shaded regions indicate the estimated coefficient and its associated $95 \%$ confidence intervals respectively. The histogram displays the distribution of the manufacturing variable. The coefficient estimate is statistically significant at $\mathrm{p}<.05$ where the confidence intervals do not include zero.

Finally, Figure 4 reveals that the marginal effect of inequality is not statistically significant across the full range of manufacturing sector size in the coup history sample (left plot). However, the right plot indicates a positive and statistically significant marginal effect of inequality between approximately $20 \%$ and $33 \%$ of manufacturing sector size in the sample of countries without a history of coups. This runs contrary to expectations, since an absence of coups ought to reflect that the military is more reliable, and thus inequality ought to have no effect. A possible explanation for this finding is that coup history may not adequately capture the reliability of a regime's military. 

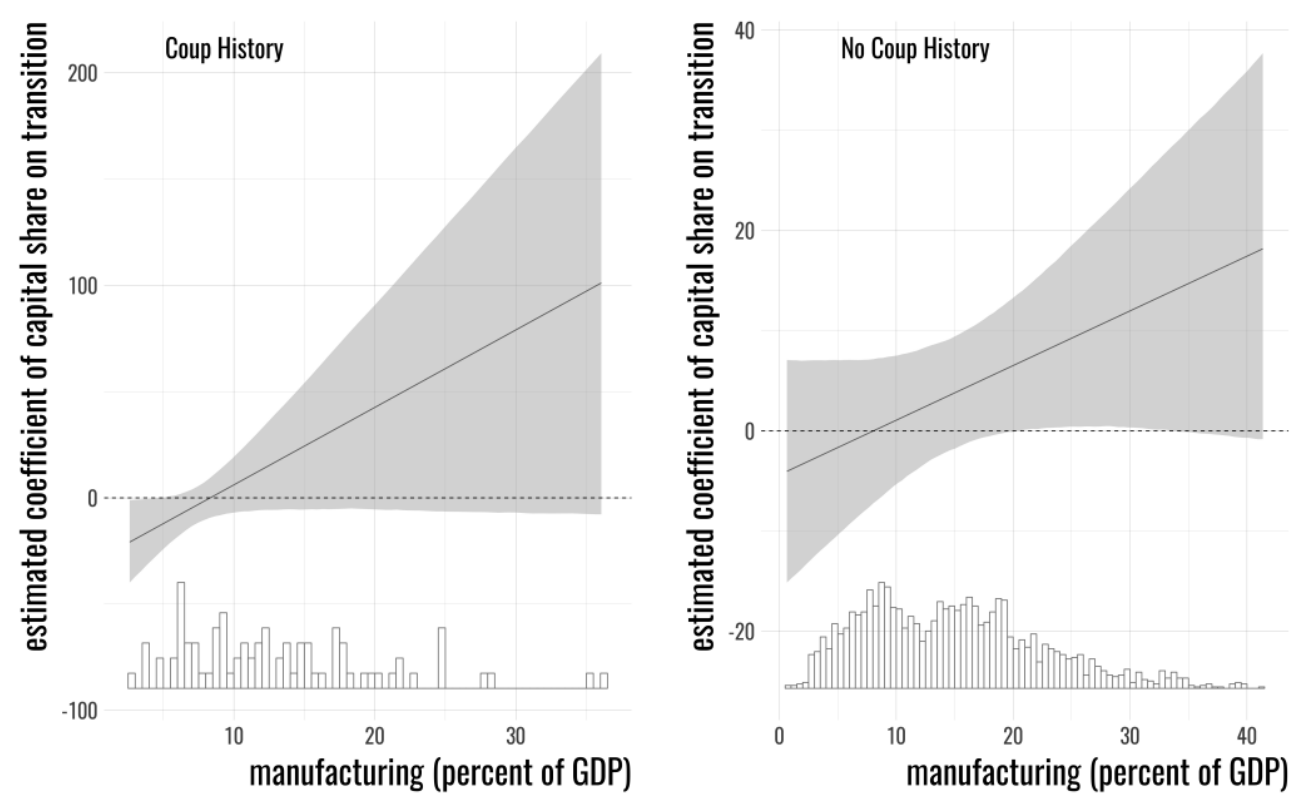

Figure 4. Marginal Effect of Inequality and Manufacturing Sector Size on Distributive Conflict Transition (Coup History)

The lines and shaded regions indicate the estimated coefficient and its associated 95\% confidence intervals respectively. The histogram displays the distribution of the manufacturing variable. The coefficient estimate is statistically significant at $p<.05$ where the confidence intervals do not include zero.

\section{The Paths To Democracy ARe Many}

There is an intuitive plausibility - as well as a formal foundation - for the idea that the establishment of democracy involves struggles over an unequal distribution of income and wealth. Yet consistent empirical evidence of such a connection has been elusive. The debate over the inequalitydemocratization relationship has unfolded at many different levels. At the individual level, reactions to inequality are far from uniform, and are shaped by perceptions of upward mobility opportunities, and religious, geographic, and ethnic cleavages. At the aggregate level, efforts to demonstrate a connection between inequality and political conflict, and between political conflict and democratization, have produced divergent, and often contradictory, results. Results of tests of the direct effects, including those in the preceding pages, are fragile: like Houle, I find that inequality has no direct effect on transitions. ${ }^{69}$ Other studies do show support for either the Boix or Acemoglu and Robinson hypotheses. ${ }^{70}$ Nonetheless, there are good reasons to beskeptical that the relationship would be straightforward.

On the other hand, we should not be especially surprised that inequality per se does not lead directly to political protest or regime change. Such processes are never simple, as Boix, and Acemoglu and Robinson themselves suggest in their formal models. The role of inequality-if it has an impact at all - should be conditional on other economic, social, and political factors; for this reason, it would be wrong to reject its causal importance out of hand. Inequality may affect some transitions under some restrictive conditions. Indeed, as indicated in the introduction, there is some evidence in the literature that - when considered jointly with capital mobility or economic development - inequality can make a difference in determining whether an authoritarian regime remains in place or a democracy emerges. $^{71}$

The findings here suggest that explanations of democratic transitions need to incorporate political and social factors - in addition to economic ones - in exploring the impact of inequality. My focus here is on socio-demographic factors that facilitate coordination and collective action, and the organizational resources that affect the ability of elites to overcome redistributive demands if and when they arise. These factors are central to the large sociological and political science literature on organization, social movements, and political institutions, ${ }^{72}$ but have been underemphasized in the existing political economy literature. I show that when the masses have the capacity to organize and mobilize and when the elites are weak, inequality can have a predictable and positive effect on the chances for a democratic transition. 
These findings are only a first step in examining these relationships more closely and systematically, but they do indicate the need to bring sociological and political factorsback into the political economy of transitions. To be sure, the time period of the present analysis (1980-2008) limits the generalization of the findings to all transitions; it is likely that Third Wave transitions differ systematically from prior and subsequent transitions. Nonetheless, the emphasis on these conditioning factors underscores the limited scope of theories that focus solely on distributional challenges: inequality will matter only in a limited subset of transitions.

Democracy and dictatorship are political processes; their origins lie not only in the economic but in the political and social.

\section{REFERENCES}

[1] ${ }^{1}$ Boix, Carles, Democracy and Redistribution (New York: Cambridge University Press, 2003); Acemoglu, Daron and James A. Robinson, Economic Origins of Dictatorship and Democracy (New York: Cambridge University Press, 2006).

[2] ${ }^{2}$ Boix; Acemoglu and Robinson; Lipset, Seymour M, "Some Social Requisites of Democracy: Economic Development and Political Legitimacy," American Political Science Review 53(March 1959), 69-105.

[3] ${ }^{3}$ Bollen, Kenneth A. and Robert W. Jackman, "Political Democracy and the Size Distribution of Income," American Sociological Review 50(August 1985), 438-457; Papaionnannou, E and G Siourounis, "Economic and Social Factors Driving the Third Wave of Democratization," Journal of Comparative Economics 36(September 2008), 365-386; Houle, Christian, "Inequality and Democracy: Why Inequality Harms Consolidation but Does Not Affect Democratization," World Politics 61(October 2009), 589-622; Houle, Christian, "Inequality, Economic Development, and Democratization," Studies in Comparative International Development 51(December 2016), 503-529.

[4] ${ }^{4}$ Boix; Boix, Carles and Susan Stokes, "Endogenous Democratization," World Politics 55(July 2003), 517-549.

[5] 5 Ansell, Ben and David Samuels, "Inequality and Democratization: A Contractarian Approach," Comparative Political Studies 43(December 2010), 1543-1574; Ansell, Ben and David Samuels, Inequality and Democratization: An Elite-Competition Approach, (New York: Cambridge University Press 2014).

[6] ${ }^{6}$ Acemoglu and Robinson.

[7] ${ }^{7}$ Freeman, John R. and Dennis P. Quinn, "The Economic Origins of Democracy Reconsidered," American Political Science Review 106(February 2012), 58-80.

[8] ${ }^{8}$ Houle 2016.

[9] ${ }^{9}$ Haggard, Stephan and Robert R. Kaufman, Dictators and Democrats: Masses, Elites, and Regime Change (Princeton: Princeton University Press 2016).

[10] ${ }^{10}$ Lipset; Boix and Stokes.

[11] ${ }^{11}$ Przeworski, Adam, Democracy and Development: Political Institutions and Well-Being in the World, 1950-1990 (New York: Cambridge University Press 2000).

[12] ${ }^{12}$ Meltzer, Allan H. and Scott F. Richard, "A Rational Theory of the Size of Government," Journal of Political Economy 89(October 1981), 917-927.

[13] ${ }^{13}$ See Wallerstein, Michael and Karl O. Moene, "Earnings Inequality and Welfare Spending: A Disaggregated Analysis," World Politics 55(July 2003), 485-516; Iversen, Torben and David Soskice, "Electoral Institutions and the Politics of Coalitions: Why Some Democracies Redistribute More Than Others," American Political Science Review 100(May 2006), 165-181, for a critique.

[14] ${ }^{14}$ As Ansell and Samuels note, "the Meltzer-Richard model was designed for application in existing democracies, meaning that the model assumes the supply of regime type as given."

[15] ${ }^{15}$ Boix; Acemoglu and Robinson.

[16] ${ }^{16}$ Acemoglu, Daron, Suresh Naidu, Pascual Restrepo, and James A. Robinson, "Democracy, Redistribution, and Inequality," Handbook of Income Distribution 213(2015), 1885-1966

[17] ${ }^{17}$ Haggard, Stephan and Robert R. Kaufman, "Inequality and Regime Change: Democratic Transitions and the Stability of Democratic Rule," American Political Science Review 106(August 2012), 495-516.

[18] ${ }^{18}$ Ansell and Samuels 2014.

[19] ${ }^{19}$ Acemoglu and Robinson 2006. 
[20] ${ }^{20}$ Boix 2003.

[21] ${ }^{21}$ Acemoglu and Robinson 2006.

[22] ${ }^{22}$ Houle 2009.

[23] ${ }^{23}$ Ansell and Samuels 2010; Ansell and Samuels 2014.

[24] ${ }^{24}$ Freeman, John R. and Dennis P. Quinn, "The Economic Origins of Democracy Reconsidered," American Political Science Review 106(February 2012), 58-80.

[25] ${ }^{25}$ Houle 2016.

[26] ${ }^{26}$ Haggard and Kaufman 2012; Haggard and Kaufman 2016; Cheibub, Jose A., Jennifer Ghandi, and James R. Vreeland, "Democracy and Dictatorship Revisited,” Public Choice 143(April 2010), 67-101.

[27] ${ }^{27}$ Boix 2003; Acemoglu and Robinson 2006.

[28] ${ }^{28}$ Ansell and Samuels 2010.

[29] ${ }^{29}$ Olson, Mancur, The Logic of Collective Action: Public Goods and the Theory of Games (Cambridge: Harvard University Press 1965).

[30] ${ }^{30}$ Boix 2003.

[31] ${ }^{31}$ Boix 2003; Acemoglu and Robinson 2006.

[32] 32 Albertus, Michael and Victor Menaldo. (2012) "Coercive Capacity and the Prospects for Democratization," Comparative Politics 44 (January 2012) (2), 151-169; Huntington, Samuel P, Political Order in Changing Societies (New Haven and London: Yale University Press 1968); Tilly, Charles, The Politics of Collective Violence (New York: Cambridge University Press 2003); Wintrobe, Ronald, The Political Economy of Dictatorship (Cambridge and New York: Cambridge University Press 1998).

[33] ${ }^{33}$ Boix 2003; Acemoglu and Robinson 2006.

[34] ${ }^{34}$ Houle 2009.

[35] ${ }^{35}$ Freeman and Quinn 2012.

[36] ${ }^{36}$ Albertus and Menaldo $(2012,166)$ further suggest that “...empirical studies of democratic transition would do well to include measures of the coercive apparatus under autocracy in order to explicitly account for the link between repression and democratization." I agree.

[37] ${ }^{37}$ An exception is Haggard and Kaufman 2016.

[38] ${ }^{38}$ Haggard, Stephan, Robert R. Kaufman, and Terence K. Teo, Distributive Conflict and Regime Change: A Qualitative Dataset, 2016.

[39] ${ }^{39}$ Haggard, Kaufman, and Teo.

[40] ${ }^{40}$ Survey evidence, however, raises doubts about this assumption. See Kenworthy, Lane and Leslie McCall, "Inequality, Public Opinion, and Redistribution," Socio-Economic Review 6(January 2008), 3568; Ansell and Samuels 2010; Cramer, Brian D. and Robert R. Kaufman, "Views of Economic Inequality in Latin America," Comparative Political Studies 44(September 2011), 1206-1237.

[41] ${ }^{41}$ Boix 2003; Acemoglu and Robinson 2006; Houle 2009.

[42] ${ }^{42}$ Acemoglu, Daron and James A. Robinson, "Why Did the West Extend the Franchise? Democracy, Inequality, and Growth in Historical Perspective," Quarterly Journal of Economics 115(November 2000 4), 1167-1199.

[43] ${ }^{43}$ Boix 2003; Acemoglu and Robinson 2006.

[44] ${ }^{44}$ Gandhi, Jennifer and Adam Przeworski, Cooperation, Cooptation, and Rebellion under Dictatorships," Economics and Politics 18(March 2006), 1-26; Gandhi, Jennifer and Adam Przeworski, "Authoritarian Institutions and the Survival of Autocrats," Comparative Political Studies 40(November 2007), 12791302; Magaloni, Beatriz and Ruth Kricheli, "Political Order and One-Party Rule." Annual Review of Political Science 13(2010), 123-143.

[45] ${ }^{45}$ Albertus and Menaldo 2012; Wintrobe 1998.

[46] ${ }^{46}$ Acemoglu and Robinson 2006.

[47] ${ }^{47}$ Carter, David B. and Curtis S. Signorino, "Back to the Future: Modeling Time Dependence in Binary Data," Political Analysis 18(Summer 2010), 271-292.

[48] ${ }^{48}$ Gelman, Andrew and Jennifer Hill, Data Analysis Using Regression and Multi-level/Hierarchical Models (New York: Cambridge University Press 2006); Bell, Andrew and Kelvyn Jones, "Explaining Fixed Effects: Random Effects Modelling of Time-Series Cross-Sectional and Panel Data," Political Science Research and Methods 3(January 2015), 133-153. 
[49] ${ }^{49}$ Haggard, Kaufman, and Teo.

[50] ${ }^{50}$ Cheibub, Ghandi, and Vreeland

[51] ${ }^{51}$ Rodrik, Dani, "Democracies Pay Higher Wages," Quarterly Journal of Economics 114(August 1999), 707-738.

[52] ${ }^{52}$ Rodriguez, Francisco and Daniel Ortega, "Are Capital Shares Higher in Poor Countries? Evidence from Industrial Surveys,"Wesleyan Economic Working Papers 2006-023.

[53] ${ }^{53}$ Houle 2016.

[54] ${ }^{54}$ Dunning, Thad, Crude Democracy: Natural Resource Wealth and Political Regimes (Cambridge: Cambridge University Press, 2008).

[55] ${ }^{55}$ Solt, Frederick, "Standardizing the World Income Inequality Database,"Social ScienceQuarterly 90(June 2009): 231-242.

[56] ${ }^{56}$ World Bank, World Development Indicators 2011. Washington, DC: World Bank 2012.

[57] ${ }^{57}$ Haggard and Kaufman 2016.

[58] ${ }^{58}$ Robertson, Graeme B. and Emmanuel Teitelbaum, "Foreign Direct Investment, RegimeType and Labor Protest in Developing Countries,"American Journal of Political Science55(July 2011), 665-677.

[59] ${ }^{59}$ Dahl, Robert A,Democracy and Its Critics (New Haven and London: Yale UniversityPress 1989).

[60] ${ }^{60}$ Albertus and Menaldo.

[61] ${ }^{61}$ Levitsky, Steven and Lucan A. Way,Competitive Authoritarianism: Hybrid RegimesAfter the Cold War (New York: Cambridge University Press 2010); Albertus and Menaldo.

[62] ${ }^{62}$ World Bank.

[63] ${ }^{63}$ Alesina, Alberto, Arnaud Devleeschauwer, William Easterly, Sergio Kurlat, and Romain Wacziarg,"Fractionalization,"Journal of Economic Growth 8(June 2003), 155-194.

[64] ${ }^{64}$ Albertus, Michael and Victor Menaldo, "If You're Against Them You're With Us: The Effect of Expropriation on Autocratic Survival," Comparative Political Studies (August 2012), 973-1003.

[65] ${ }^{65}$ Boix, Carles, Michael K. Miller, and Sebastian Rosato, "A Complete Data Set of Political Regimes, 1800-2007," Comparative Political Studies 46(December 2013), 1523-1554.

[66] ${ }^{66}$ Chinn, Menzie D. and Hiro Ito, “A New Measure of Financial Openness,” Journal of Comparative Policy Analysis 10(September 2008), 309-322.

[67] ${ }^{67}$ Houle 2009; Haggard and Kaufman 2016.

[68] ${ }^{68}$ Braumoeller, Bear F, "Hypothesis Testing and Multiplicative Interaction Terms," International Organization 58(Autumn 2004), 807-820; Brambor, Thomas, William Roberts Clark, and Matt Golder, "Understanding Interaction Models: Improving Empirical Analyses," Political Analysis 14(Winter 2006), 63-82.

[69] ${ }^{69}$ Houle 2009.

[70] ${ }^{70}$ Boix 2003; Acemoglu and Robinson 2006.

[71] ${ }^{71}$ Houle 2016.

[72] ${ }^{72}$ Rueschemeyer, Dietrich, Evelyne Huber Stephens and John D. Stephens, Capitalist Development and Democracy (Chicago: University of Chicago Press 1992); Collier, Ruth, Paths Toward Democracy: The Working Class and Elites in Western Europe and South America (Cambridge: Cambridge University Press 1999); McAdam, Doug, Sidney Tarrow and Charles Tilly, Dynamics of Contention(Cambridge: Cambridge University Press 2001); Tilly 2003; Walder, Andrew G, "Political Sociology and Social Movements."Annual Review ofSociology 35(2009), 393-412.

Citation: Terence K. Teo. "Rousing the Rabble: Coercion, Coordination, and Regime Change" International Journal of Political Science (IJPS), vol 7, no.1, 2021, pp. 01-14. doi: https://doi.org/10.20431/24549452.0701001.

Copyright: (C) 2021 Authors. This is an open-access article distributed under the terms of the Creative Commons Attribution License, which permits unrestricted use, distribution, and reproduction in any medium, provided the original author and source are credited. 